\title{
The Interaction of Private and Public Governance: The Case of Sustainability Standards for Palm Oil
}

\author{
Clara Brandi ${ }^{1}$
}

Accepted: 20 September 2020 / Published online: 12 October 2020

(c) The Author(s) 2020

\begin{abstract}
By providing insights into the interaction between private-driven and public-driven governance initiatives in the context of the "Roundtable of Sustainable Palm Oil" (RSPO) and the "Indonesian Sustainable Palm Oil" (ISPO), this article sheds new light the interaction between private and public governance. It investigates how the relationship between the RSPO and the ISPO evolves over time and who and what drives this evolution. While the interaction between these standard schemes has initially largely been characterized by competition, it has become more collaborative and also coordinated in nature. This article argues that the experimentalist architecture of palm oil governance has fostered mechanisms for coordination across public and private certification schemes and has helped to join up the separate components of the regime complex through productive interactions. At the same time, several gaps and challenges remain, especially in light of the different interests of the multiple public and private actors involved in palm oil.
\end{abstract}

Keywords Sustainability standards · RSPO - ISPO · Transnational interlinkages · Experimental governance $\cdot$ Transnational regime complex $\cdot$ Palm oil $\cdot$ Indonesia

\section{Résumé}

En fournissant des informations sur la façon dont les initiatives de gouvernance publiques et privées interagissent dans le contexte de la «Table ronde sur l'huile de palme durable» (RSPO) et «l'huile de palme durable indonésienne» (ISPO), cet article offre un nouvel éclairage sur l'interaction entre gouvernance publique et gouvernance privée. Il étudie l'évolution de la relation entre la RSPO et l'ISPO au fil du temps, ainsi que les acteurs et les facteurs qui sont les moteurs de cette évolution. Bien que l'interaction entre ces programmes standards ait été initialement largement caractérisée par la concurrence, elle est devenue plus collaborative, et plus coordonnée par nature. Cet article soutient que l'architecture expérimentale de la gouvernance

Clara Brandi

Clara.Brandi@die-gdi.de

1 German Development Institute/Deutsches Institut für Entwicklungspolitik (DIE), Bonn, Germany 
de l'huile de palme a favorisé des mécanismes de coordination entre les systèmes de certification publics et privés et a permis de réunir les composantes distinctes du complexe de régimes grâce à des interactions productives. Dans le même temps, plusieurs lacunes et défis subsistent, en particulier à la lumière des intérêts divergents des multiples acteurs publics et privés impliqués dans l'industrie de l'huile de palme.

\section{Introduction}

Transnational business governance-for example, certification schemes for fish or palm oil, fair trade labels or accounting and transparency standards- has become more widespread and important, both as a novel mode of regulation to promote sustainable development and as a study subject of scholarly research. Transnational business governance entails business regulation emanating not from traditional state and interstate institutions but a variety of institutions from the private sector and civil society as well as multi-stakeholder institutions (Eberlein et al. 2014). Lately, more attention has been given to the fact that transnational governance schemes do not exist in a regulatory vacuum but interact with each other and with other regimes. Accordingly, there has been a stronger focus on transnational interlinkages (Hickmann et al. 2020) or transnational business governance interactions (Eberlein et al. 2014) - that is, the various ways in which non-state actors and institutions engage with and react to one another or state-based regimes. Complementing analyses of the interaction of different types of governance forms in domains such as forestry, fishery, and financial markets, the present study puts the spotlight on the palm oil sector and its sustainability challenges.

In the past, a number of scholars have underlined a trend from state-led towards less state-led approaches and stressed the ever more important role of private governance (Pattberg 2012). This article contributes to the literature that investigates how public actors and their rule-making activities have responded to this move towards private governance. Recent studies acknowledge that governments can foster or hamper private governance initiatives but that the various interactions between private sector and public authority in the governance of environmental and social challenges are still an understudied field of global governance (c.f. Gulbrandsen 2014). There is thus a need for more detailed assessments of the relationships between public and private actors in transnational governance in that regard.

This article focuses on the interaction between private-driven and public-driven certification schemes. Certification has long been conceptualized as a purely "nonstate market-driven governance system" (Cashore 2002) that gains rule-making authority as a private governance institution. Recent empirical findings suggest that public actors, especially in developing countries, begin "reclaiming certification authority through state-led mandatory schemes" (Giessen et al. 2016, p. 72), complementing and/or undermining private, transnational certification institutions. ${ }^{1}$ While there are several studies that explore the interaction between public and

\footnotetext{
1 On the role of stakeholders in developing countries in the context of private transnational governance, see Dingwerth (2008). For a discussion of the role of the state in developing countries in the context of green economy policies, see Lederer et al. (2018).
} 
private standards (e.g. Hospes 2014; Giessen et al. 2016; Wijaya and Glasbergen 2016; Pacheco et al. 2018; Pramudya et al. 2018), this still represents a comparatively novel research area, especially in the context of sustainability standards that address social and environmental issues.

Against this background, the objective of this article is to investigate the interaction between private-driven and public-driven schemes that are reshaping the landscape of natural resources governance systems by reviewing and discussing transnational governance and certification initiatives in the context of the palm oil sector in Indonesia. Palm oil production not only generates substantial positive socio-economic benefits, but also has significant negative social and environmental impacts, including reduced biodiversity and, especially when forest and peatlands are replaced, massive greenhouse gas emissions. As the most important producer and exporter of palm oil globally and home to some of the world's largest tropical forests and peatlands, Indonesia has struggled to address sustainability concerns and thus serves as an excellent case study for the interlinkages between public and private governance approaches. Mounting public pressure on companies and governments has led to the emergence of certification schemes in the palm oil sector-most notably, the private "Roundtable on Sustainable Palm Oil" (RSPO) and the more recently established "Indonesian Sustainable Palm Oil" (ISPO) scheme. The RSPO is a voluntary multi-stakeholder scheme and was established to fill the gap that public actors have failed to effectively govern. The ISPO is a mandatory government-led certification scheme and was the first national standard of its kind. Following the introduction of the new ISPO standard, there are questions about what this implies for the character of the interaction between RSPO and ISPO and about privatedriven and public-driven certification schemes more generally.

This article investigates how the relationship between the RSPO and ISPO evolves over time and who and what drives this evolution. It also examines the interactions between the RSPO and other public and private components of the emerging transnational sustainable palm oil regime, in particular ISPO, from an experimentalist governance perspective (Overdevest and Zeitlin 2014). The article argues that the experimentalist architecture of existing governance approaches has fostered productive interactions across public and private schemes and initiatives and that something like a "joined-up transnational regime" (Zeitlin and Overdevest 2019) has emerged over the past years from these interactions within the "transnational regime complex" for palm oil governance (Abbott 2014).

The next section introduces the analytical framework and the method employed by this study. After the presentation of the empirical findings on the interaction of RSPO and ISPO and the nature of the emerging transnational regime for sustainable palm oil in subsequent sections, the final part of the article provides concluding comments.

\section{Analytical Framework and Method}

With more and more institutions being created for novel, interrelated issues, they began to increasingly generate institutional interactions, also referred to as institutional interlinkages, institutional interplay or institutional overlap (c.f. Hickmann et al. 2020). Researchers have made use of a very broad array of theoretical 
approaches to study such institutional or governance interactions. Rationalists assess governance interactions with regard to bargaining among rational actors in light of their power (e.g. Abbott and Snidal 2009), whereas sociologists stress the role of legitimation and how it affects interactions (Bernstein and Cashore 2007; Gulbrandsen 2014). Meanwhile, institutionalists highlight how interaction is driven by structural forces emerging within organizational contexts (e.g. Bartley 2007). An increasing number of scholars assess "steering" mechanisms and explore, for instance, how actors "orchestrate" interactions (Abbott and Snidal 2009), while others emphasize learning and benchmarking (e.g. Overdevest and Zeitlin 2014, 2018) (see also below). Moreover, researchers focused on regime complexity underline the links between overlapping and parallel regimes (e.g. Raustiala and Victor 2004; Zelli and van Asselt 2013), whereas those focused on institutional interplay examine how institutions affect each other (Oberthür and Stokke 2011). Whereas both regime complexity and institutional interlinkages approaches have so far put the spotlight mostly on intergovernmental arrangements (Alter and Meunier 2009, p. 13), albeit with exceptions (e.g. Abbott 2012; Pacheco et al. 2018), this article goes beyond the assessment of intergovernmental approaches. As a recent review of the literature emphasizes, there is a need for more research on transnational interlinkages between institutions established by state and non-state actors (Hickmann et al. 2020), and this article seeks to contribute to this endeavour by investigating the interactions between private and public governance approaches in the palm oil sector.

More specifically, this article focuses on the interlinkages between private-driven and public-driven transnational governance in the form of certification schemes. Third-party labelling and certification initiatives have been a lively area of assessment for social science research. In that context, this type of initiative has typically been conceptualized as a "non-state market-driven governance system" (Cashore 2002). At the same time, more recent studies indicate that state actors also have an important role in the establishment, diffusion, and, potentially, the modification of (private) certification systems (Hysing 2009; Bell and Hindmoor 2012; Gulbrandsen 2014). Above all, this has been illustrated in the context of the recent rise of statedriven timber legality certification schemes (Overdevest and Zeitlin 2014). Recent studies on these and other certification schemes foreground the role of the state or state bureaucracies in private regulation (Bartley 2014; Gulbrandsen 2014) and also highlight co-governance and co-regulation between private sector and public-sector actors and institutions in the context of certification initiatives (Cashore et al. 2004; Bartley 2014; Gulbrandsen 2014). While certification initiatives have mostly been understood as instances of pure private governance, the analysis of certification initiatives in the palm oil sector and their interaction reveals a move from privatedriven governance to public-driven governance in the context of certification and sheds new light on transnational business governance interactions.

For the sake of analytical clarity, this article uses the framework developed by Eberlein et al. (2014), focusing on the character of the pertinent interaction at stake. First, there might be competition, for example, for "regulatory 'turf', revenue, reputation, legitimacy, adherents, or other benefits", including "authority to define key terms" (Eberlein et al. 2014, p. 12) like sustainability. To provide a more fine-grained analytical framework, this article distinguishes between three types of 
competition: multilevel governance competition (between the national and the international level), discursive competition (for the right to define "sustainability"), and economic competition (for market shares). Second, there might be coordinationranging from emulation to mimesis to deliberate collaboration to the conscious division of labour - as governance schemes seek "legitimacy and relevance, learn from each other and copy proven 'recipes for success"' (Eberlein et al. 2014, p. 12). Third, there might be co-optation, entailing, for instance, "meta-regulation, hegemony, or dominance" (Büthe 2010). Fourth, there might be chaos-that is, unpredictable, undirected interaction which displays no clear pattern.

As recent studies indicate, state actors may play a crucial role in private-driven certification schemes by using their power to either foster or hamper them (Cashore et al. 2004; Gulbrandsen 2014; Giessen et al. 2016) based on coordinated or competitive interaction while chaos and co-option seem to play a less prominent role. On the one hand, governments can support or facilitate such schemes by funding participation, by facilitating them through public procurement policies or applying certified standards to their own practices, by modifying the institutional context of certification schemes in their favour as well as norms and principles, for example by pushing suppliers to get certified to a private standard, by offering financial incentives or technical assistance or coordination with state-led approaches, thereby strengthening legitimacy (Hysing 2009; Gulbrandsen 2014). On the other hand, state actors can restrict certification schemes by setting up competing initiatives or by creating rules or modifying norms that limit or hamper certification initiatives (Gulbrandsen 2014).

There is no consensus yet on the effects of transnational governance interactions. Important dimensions of their effects are regulatory effectiveness and fragmentation. First, while various scholars have investigated the implications of interactions for regulatory effectiveness, there is no agreement on whether they generate a race to the bottom or a race to the top (Eberlein, et al. 2014). There are studies which indicate that the implications of the interaction depend on the industry structure at stake (Cashore et al. 2004). Some scholars are optimistic and point out that public pressure in combination with regulatory competition can increase standards (Overdevest 2010). Other studies indicate that competition (for acceptance etc.) can foster more transparency, ambition, and effectiveness (Meidinger 2008) or rule convergence (Smith and Fischlein 2010). Others stress that upward convergence might be primarily shallow, concealing considerable deviation among the relevant standards (Fransen 2011). The literature on regime complexity tends to have a more pessimistic outlook on interaction, highlighting rule inconsistencies or the potential for strategic forum shopping (Raustiala and Victor 2004; Alter and Meunier 2009; Pacheco et al. 2018).

Second, despite a growing literature on fragmentation in global governance (e.g. Zelli and van Asselt 2013), whether the interaction of transnational business governance initiatives leads to more or less institutional fragmentation remains an open question. This article takes up this question in the context of private-driven and publicdriven certification and discusses to what extent the relationship between these two forms of governance leads to more fragmentation - that is, the degree to which policy domains are marked by a "patchwork" of institutions that differs in terms of their character, their constituencies, their spatial scope and their subject matter (Biermann et al. 2009, p. 16). 
As indicated above, the interactions between RSPO and ISPO will also be investigated from an experimentalist governance perspective. Experimentalist governance entails flexible problem solving arrangements and develops in the course of dynamic interactions between private-public and global-domestic governance, with actors defining the goals and revising the governance architecture iteratively in light of comparing alternative approaches in various settings and learning about their promises and pitfalls (Overdevest and Zeitlin 2014, 2018), often reinforced by a "penalty default" that addresses non-cooperation with the experimentalist regimes (Overdevest and Zeitlin 2018). This is a promising lens because the literature has shown that interactions among different schemes and initiatives can be shaped by experimentalist approaches (Overdevest and Zeitlin 2014) and standards schemes for palm oil in Indonesia, engaging both public and private actors, can be conceptualized as a form of experimentalist governance. While this has briefly been touched upon in the literature (Pacheco et al. 2018), palm oil governance and the interaction between RSPO and ISPO have not been assessed in detail from this perspective.

The experimentalist architecture of palm oil governance is based on wide-ranging involvement of public and private stakeholders in creating and revising broad goals, i.e. promoting sustainable palm oil and reducing deforestation, and metrics for examining progress towards them, such as RSPO principle and criteria (P\&C), ${ }^{2}$ through steady review, leading to the revision of goals, standards and procedures. $^{3}$ For example, the RSPO, like the Forest Stewardship Council (FSC), "has many experimentalist features, including not only its multi-stakeholder governance structure and deliberative decision-making procedures, but also its broad, principlesbased standards, adapted to local conditions by national or regional chapters; continuous monitoring, independent verification" (Overdevest and Zeitlin 2014, p. 7). More generally, in the context of the Indonesian palm oil sector, as will be argued in this article, a variety of different actors is engaging in iterative adjustments of governance approaches to revise sustainability standards and regulations to overcome inconsistencies and promote synergies. The literature on experimentalist governance suggests that experimentalist mechanisms can contribute to tackling coordination challenges among different standards (Overdevest and Zeitlin 2014) and this article will argue that coordination across standards and schemes in the palm oil sector is indeed determined by experimentalist mechanisms such as benchmarking and the establishment of joint committees.

Building on the analytical framework for transnational business governance interaction and the literature on experimentalist governance, the present article employs a qualitative case study approach to investigate the interaction between privatedriven and public-driven governance in the context of certification. Both data from primary and secondary sources form the basis of this research. Data collected from various sources were used to examine the character of the interaction between the

\footnotetext{
${ }^{2}$ The RSPO principles and criteria (P\&C) are a set of requirements for palm oil production, which RSPO members must comply with.

${ }^{3}$ For a discussion of the experimentalist character of the governance architecture in forestry, see Overdevest and Zeitlin $(2014,2018)$.
} 
two types of governance approaches. In order to gather information on the relevant certification processes and to identify key actors, secondary data were collected using a literature search that focused on academic and professional journals and the websites of certification bodies, companies, NGOs, professional associations, relevant bureaucracies and the media. To collect primary data, semi-structured interviews were carried out between 2012 and 2020 with experts in private certification and state-certification processes as well as other stakeholders in the palm oil sector by using different methods, including personal meetings during fieldwork carried out in Indonesia, teleconference as well as e-mail exchanges.

This article represents an actor-centred and institutionalist approach (in that it assumes that the interests and preferences of actors are endogenous) and occupies a middle ground between a purely constructivist approach (which would exclusively focus on interacting discourses) and a purely rational approach (which would only consider interactions between individual calculating agents) (c.f. Eberlein et al. 2014).

\section{Governance Interaction in Sustainable Palm Oil Governance}

This section investigates how the relationship between the RSPO and the ISPO has evolved, comparing the period of the launch of ISPO to more recent developments in this relationship. The analysis will show that the relationship has moved from more competitive towards more coordinated interactions that have helped to join up the separate elements of palm oil governance. The section will also show that the evolving relationship between the RSPO, mostly driven by non-state actors like buyers but also NGOs, and the ISPO, driven largely by the Indonesian government, is complicated because of the nature of the Indonesian state being fragmented due to decentralization and numerous Ministries and agencies involved in palm oil, ${ }^{4}$ shaping the relationship across various levels (local, regional and national levels of government) and with multiple public and private actors and overlapping policies in the palm oil sector. ${ }^{5}$

\section{Competitive Interaction}

Analysis of statements and interviews with stakeholders shows that the ISPO was established as a rival "in direct competition with the RSPO" (Wadley and Doherty 2013). The launch of ISPO signified the national government (re)taking its role in governing the sustainability of the palm oil sector, openly criticising RSPO and thereby ending an initial phase of seeming acceptance of the latter (Hospes 2014; Giessen et al. 2016; Wijaya and Glasbergen 2016). The notion of competition has thus played a key role in the interplay between the public- and the private-driven

\footnotetext{
${ }^{4}$ I am grateful to an anonymous reviewer for underlining this important point.

5 Interview, 13 December 2019.
}

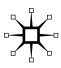


initiative. This is evidenced by three overlapping phenomena: a power struggle between the national level and the international level, a discursive struggle over the definition of sustainability, and competition for market share in the global economy.

Firstly, the establishment of ISPO occurred within the context of a struggle between the national level (especially the government and domestic producers) and the international level (above all, international NGOs that are influential in the RSPO). The RSPO is portrayed as putting the interests of consumer countries above those of producer countries like Indonesia and Malaysia. Experts interviewed for this article also acknowledged that various Indonesian players, including associations like the Indonesian Palm Oil Association GAPKI, had criticized the RSPO for being driven by NGOs and Western companies. For that reason, there was a feeling among these actors, nationally, that Indonesia should be in the driving seat and look to create its own standard. ${ }^{6}$ In 2011, GAPKI officially withdrew from the RSPO, stressing that the RSPO was unbalanced at the expense of producers (TROPIS 2011). In this respect, ISPO seemed to allowed Indonesia to escape a situation in which it was subject to Europe (Hakim 2010). The interviewed Indonesian stakeholders also explicitly stressed that the RSPO was regarded as problematic from a sovereignty perspective and considered to have been forced upon Indonesians. ${ }^{7}$ In summary, a major reason behind the establishment of ISPO was to challenge the RSPO and to re-establish the national government's authority in the Indonesian palm oil sector (Hospes 2014; Giessen et al. 2016; Wijaya and Glasbergen 2016), reflecting the government's longing for a stronger role and for national sovereignty in the context of the Indonesian palm oil sector. The creation of ISPO was thus strongly shaped by the objective of promoting a vision of sustainability that was driven by Indonesian (government) rather than by international (non-state) players (Suharto 2010).

Secondly, the establishment of ISPO can also be regarded as an expression of concern about the definition of sustainability in the Indonesian palm oil sector. Around the launch of ISPO, there has been an intense discursive struggle between NGOs, on the one hand, and the Indonesian authorities and a number of palm oil producers, on the other, about the meaning of sustainability in terms of its economic, environmental, and social dimensions (Hospes and Kentin 2012). According to one government official, the adherence of all palm oil producers to the mandatory ISPO would be sufficient proof that Indonesian production is sustainable. ${ }^{8}$ However, NGOs are doubtful that ISPO is "anything more than an attempt to permit the oil palm industry in Indonesia to continue business as usual practices while being seen to apply some kind of sustainability criteria" (Jakarta Post 2010). Numerous stakeholders view ISPO as a smokescreen to convince buyers that environmental problems are being addressed. ${ }^{9}$ During an interview, one NGO member stated that ISPO deems things as "sustainable" that are not allowed under the RSPO. ${ }^{10}$ Other experts

\footnotetext{
${ }^{6}$ Interview, 20 February 2012.

7 Interview 22 January 2012.

8 Interview, 20 February 2012.

9 Interview, 22 February 2012.

10 Interview, 10 March 2012.
} 
confirm that ISPO is often criticized for being a "greenwashing" instrument. ${ }^{11}$ While a coalition of several NGOs and international companies is focused mainly on social and environmental issues, a coalition of Indonesian palm oil producers and the Indonesian authorities sees palm oil as an opportunity for economic growth. For instance, at the 2011 GAPKI Conference participants stated that Indonesian palm oil producers considered environmental sustainability to be less important than economic prosperity (Kentin 2012). When it was launched, ISPO was as a competitor to the RSPO insofar as it expresses a narrowly conceived notion of economic sustainability rather than a more holistic view that encompasses economic, social, and environmental sustainability.

Thirdly, the empirical evidence indicates that the launch of ISPO can also be regarded as an expression of concern about economic competition. According to several public statements, competition for market share was an important driver behind the launch of ISPO. For instance, Rosediana Suharto, ISPO's Executive Chairperson, made clear that the aim of ISPO is to enhance the competitiveness of the Indonesian palm oil sector in global markets (Suharto 2010). As stated in an interview with an Indonesian ministry employee, ISPO is expected to improve the competitiveness of Indonesian palm oil by increasing yield and quality through agricultural practices. ${ }^{12}$ According to another expert, the goal is to turn ISPO, which has been introduced as a national standard, into an internationally accepted standard in global markets. ${ }^{13}$ Meanwhile, the chairman of GAPKI has claimed that the existence of both the RSPO and ISPO and "the variation in certification and organizations will encourage healthy competition in producing sustainable palm oil" (Jakarta Post 2011). The hope was that that Indonesian palm oil being certified as sustainable under the ISPO would increase the commodity's competitiveness, including by improving the efficiency of the palm oil sector.

Overall, by the time of the introduction of the national standard ISPO, the interaction between the different standards was competitive in nature. By illustrating that the launch of ISPO was largely driven by Indonesian state actors feeling disadvantaged by the establishment of the RSPO, this study supports the finding that the "impetus for creating a competing network most often stems from groups of stakeholders that are either excluded from the creation of the initial effort or feel disadvantaged by the course its development is taking" (Smith and Fischlein 2010, p. 514).

As different certification schemes were established, some firms did focus on the RSPO, while other companies, including Astra Agro Lestari, Indonesia's secondlargest palm oil producer by area, opted for the competing national scheme, leading to governance that seems highly fragmented at first sight. ${ }^{14}$ The concern about competition and fragmentation triggered the introduction of additional national standards in other sectors and in other countries. For example, after the establishment

11 Interview, 20 February 2012.
12 Interview, 20 February 2012.
13 Interview, 17 February 2012.
14 For a similar trend in forestry, see Cashore et al. (2004). 
of the ISPO, the Indonesian government created a mandatory certification system for the forestry sector (Giessen et al. 2016) and made similar advances in the coffee and the cocoa sector (Wijaya and Glasbergen 2016). Moreover, the launch of ISPO triggered the introduction of additional, potentially competing national standards for palm oil. In 2013, Malaysia-ranking second in palm oil production behind Indonesia-introduced the Malaysian Sustainable Palm Oil (MPSO) standard, explicitly "following in the footsteps of Indonesia" (Adnan 2013), which became mandatory by the end of 2019 .

\section{Increasingly Coordinated Interaction}

While the interaction between the ISPO and the RSPO has, especially initially, largely been characterized by competition, public disputes between proponents of the RSPO and ISPO do not imply that there is no cooperation or coordination. Indeed, private talks between RSPO representatives and Indonesian officials reveal a perception that they see RSPO and ISPO actually complementing each other. According to the interviewed RSPO experts, the relationship between the RSPO and ISPO, after the creation of the latter, was like a "secret love affair" that could not be revealed to the world. In 2019, an expert confirmed that there are good relations between RSPO and ISPO. ${ }^{15}$

As will be argued in what follows, despite the earlier signs of competition between the RSPO and ISPO, there has been an increasing trend towards more cooperation between both schemes. In fact, in the more recent past, the relationship between the RSPO and ISPO has become more coordinated in nature-not just behind closed doors but also in public. And, while a certain degree of fragmentation remains, there are some key mechanisms that have promoted more positive interactions between the standards schemes. Rather than pure fragmentation and competition, interaction among the schemes has resulted in regular exchanges, learning, adjustments and signs of alignment and convergence. ${ }^{16}$

The increasing attempts to promote cooperation between RSPO and ISPO has been driven by the growing recognition of the difficulties that the national ISPO standard faced in terms of being accepted in international markets by major importers and manufacturers of consumer goods (Hidayat et al. 2018, Pramudya et al. 2018). Many companies consider compliance with the RSPO to be more important than with ISPO, arguing that the former is more trusted by their buyers, notably those in Europe and the United States (Grazella 2014). As Rosediana Suharto put it in an interview in 2018: "We are overpowered by the RSPO...The ISPO and RSPO were meant to be two complementary palm oil sustainability standards for the Indonesian palm oil sector... If it [ISPO] aims for business competition, we need to adjust the standards in accordance with international demand" (Pradipta 2018). Overall, there has been growing acknowledgement of the futility of directly

15 Interview, 11 December 2019.

16 For a discussion of these mechanisms in the case of the FSC, see Overdevest and Zeitlin (2014). 
opposing RSPO and increasing openness to cooperate across the different standard schemes. ${ }^{17}$

Another key driver of more coordinated interaction between the different standards has been the EU's plans to adjust its renewable energy policies. In 2009, the Renewable Energy Directive (RED) specified sustainability requirements for biofuels in the EU, including palm oil, to be eligible to count toward EU renewable transport targets. ${ }^{18}$ In 2019, the EU Commission reformed RED and ruled that palm oil, with some exceptions (such as sustainable palm oil produced by smallholders), will not be eligible to count toward EU renewable transport targets due to the risk of it being a linked to substantial deforestation. In the context of the framework of experimental governance, this reform of the EU approach can be interpreted as amounting to a penalty default (Overdevest and Zeitlin 2018) that seeks to address non-cooperation. ${ }^{19}$ In light of the EU's concern about deforestation, the Indonesian government, namely Vice President Ma'ruf Amin, recently reiterated the goal of using ISPO to combat the negative image of the Indonesian palm oil sector (Akhlas 2019). The policy change in the EU puts pressure on producing countries like Indonesia and has increased the need to rethink the standard landscape and the interaction of the different standard schemes, reflecting on options for adjustments and learning.

The increasing coordination between RSPO and ISPO was largely driven by state actors, among them the Ministry of Agriculture, the Coordinating Ministry of Economic Affairs and the National Development Planning Agency (BAPPENAS). For example, the BAPPENAS suggested already briefly after the launch of ISPO that RSPO P\&C implementation should be combined with ISPO regulation enforcement (Haryana 2010). The Vice Minister of Agriculture hoped that RSPO would acknowledge ISPO as a condition to satisfy the RSPO principle that demands that palm oil cultivation complies with national regulations (Subagyo 2013). In interviews with members of the RSPO in Indonesia, ISPO was described as a positive step towards achieving compliance with existing Indonesian legislation. ${ }^{20}$ Coordination and cooperation between the two standards were also promoted by international organizations, above all UNDP, in close cooperation with state actors such as the Ministry of Agriculture, in order to reduce time and costs for all palm oil producers having to comply with both schemes. ${ }^{21}$

\footnotetext{
17 I am grateful to an anonymous reviewer for asking me to make this point more explicit.

18 From the perspective of experimental governance, this can be characterized as the EU aiming at extending its "internal regulations to transnational supply chains" (Overdevest and Zeitlin 2014, p. 7).

19 I am grateful to an anonymous reviewer pointing to the importance of the concept of the "penalty default".

20 Interview, 17 February 2012.

21 The role of UNDP in the Indonesia palm oil sector arguably can be characterized as "orchestrator" (Abbott and Snidal 2009), with the international organization providing ideational support and material incentives, for example funding for FoKSB.
} 


\section{Mechanisms for Coordination Through an Experimentalist Governance Lens}

As indicated above, experimentalist approaches can contribute to tackling coordination challenges among different standard schemes. An examination of the coordination of actors and standards within the emerging regime of palm oil governance illustrates that it is indeed driven by two experimentalist mechanisms that will be laid out in what follows.

The first key mechanism to promote coordination in the literature on experimental governance is the undertaking of benchmarking and public comparative analyses (Overdevest and Zeitlin 2014). In fact, such a process of benchmarking of different palm oil standards has been undertaken by several stakeholders, including NGOs, academics and international organizations (e.g. Forest Peoples Programme 2017; IUCN 2019), and RSPO compiled them and made them available on their website. Moreover, the ISPO and the RSPO cooperated to undertake a joint ISPORSPO study, ${ }^{22}$ published by the Indonesian Ministry of Agriculture and supported by UNDP, to assess similarities and differences between the two schemes. The goal of the study, and the public comparison it entailed, was to foster synergies and cooperation, aiming at better aligning ISPO and RSPO, and to streamline the certification process (Suharto et al. 2015). The joint study was a promising step into the direction of coordination and reconciliation in line with experimentalist governance. For example, the identification of similarities between RSPO and ISPO in the joint study was regarded as a basis for a joint audit of both standards (Suharto et al. 2015). In fact, according to the RSPO chairperson, the RSPO started working on a joint certification initiative with ISPO. ${ }^{23}$ During the drafting process, the Vice Minister of Trade suggested a process for cooperation and proposed the creation of a joint standard that would be open to non-RSPO members (RSPO 2014).

While the follow-up on a joint audit system of ISPO and RSPO has so far been limited, ${ }^{24}$ and according to an interviewed expert, is not easy to realize, ${ }^{25}$ the comparison of ISPO and RSPO contributed to some alignment between the standards. ISPO and RSPO started off far apart in terms of both substantive and procedural aspects. The ISPO initially lacked independent audits, stakeholder consultations, regular revisions and performance-based principles and assessment criteria but has over time moved closer to the RSPO on these dimensions. To promote ISPO and its legitimacy, the Indonesian state was under pressure to start a process of "Strengthening ISPO", which began in 2016. The aim of the process was to improve ISPO and its credibility by revising ISPO $\mathrm{P} \& \mathrm{C}$, generating criteria for plantation development, community consultation mechanisms and legal conflicts in the context of High Conservation Value (HCV) protection and by founding an accreditation body and a third-party auditing and monitoring process but also reforming the ISPO

\footnotetext{
22 Interview, 24 December 2019.

23 RSPO planned to undertake a similar endeavour with the newly launched Malaysian Sustainable Palm Oil (Damodaranuala 2014).

24 Interview, 13 December 2019.

25 Interview, 11 December 2019.
} 
organizational structure, addressing legality and developing an international diplomacy strategy for promoting ISPO. The goal was also to alter ISPO from a Ministry of Agriculture Regulation into a Presidential Regulation. In March 2020, the new Presidential Regulation on ISPO was enacted and introduced important changes, including the abolishment of exceptions for those that produce palm oil for renewable energy, the creation of an ISPO certification body, similar to the RSPO system, and the introduction of sanctions, i.e. penalty defaults, for those who fail to obtain ISPO certification (Suwarganda 2020).

The process of "Strengthening ISPO", led by the Coordinating Ministry of Economic Affairs, was meant to be participatory, engaging different stakeholders, including state agencies and environmental NGOs, and time and again their views clashed. For instance, a grouping of NGOs proposed the inclusion of human rights, traceability and transparency into the new ISPO (Forest Watch Indonesia 2017). While the ISPO committee rejected the inclusion of human rights, after fierce discussion, it announced that it would incorporate the latter two aspects (Astari and Lovett 2019). Moreover, the concept of HCV is now included within the new ISPO's P\&C (Aisyah 2018). In parallel, the Ministry of Environment and Forestry has been working to protect important ecosystem areas in palm oil concessions and this will lead to an additional improvement of ISPO (Pacheco et al. 2018). More generally, the process of "Strengthening ISPO" generated ample opportunities for cooperation between ISPO and RSPO. In fact, RSPO was invited by the Indonesian government to provide inputs for "Strengthening ISPO". There was a good exchange and the outcome of the process of "Strengthening ISPO" is deemed adequate by RSPO experts. ${ }^{26}$ In short, the experimentalist mechanism of benchmarking has contributed to fostering positive interactions and improving coordination among the different standard schemes.

A second mechanism to tackle coordination challenges among different standards discussed in the experimentalist governance literature is to create joint committees that include national and transnational actors and focus on reviewing sustainability standards and their implementation (Overdevest and Zeitlin 2014). For instance, in the case of the Indonesian implementation of the EU's initiative on Forest Law Enforcement, Governance and Trade (FLEGT), such a committee involving public and private actors in a multi-stakeholder process to create and implement a timber standard and legality assurance system made recommendations to improve implementation and to revise the underlying standards and procedures of FLEGT (Obidzinski et al. 2014; Zeitlin and Overdevest 2019). In fact, the Indonesian government, together with UNDP, initiated a process to reproduce these experiences in the context of the palm oil sector (Pacheco et al. 2018).

In the case of ISPO and RSPO, the establishment of a joint committee consisting of representatives from various stakeholders, including government, the private sector, professional associations, NGOs and academics, under the coordination of the Indonesian government and strongly promoted by UDNP, plays a key role for the coordination among the two standards. In 2014, the Forum Kelapa Sawit

${ }^{26}$ Interview, 11 December 2019.

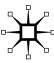


Berkelanjutan Indonesia (FoKSBI), i.e. Indonesian Sustainable Palm Oil Forum, formerly called the Indonesia Palm Oil Platform (for an analysis of the Platform, see also Pramudya et al. 2018), was founded as a neutral institution where stakeholders can share their perspectives, enhance coordination and foster consensus-building. In 2018, members of the FoKSBI presented the draft of a National Action Plan (NAP) for sustainable palm oil, which seeks to improve the sustainability of the Indonesian palm oil sector, which was signed by the President in November 2019. The FoKSBI successfully supported the government in developing the NAP, which has been drafted in a consultative and inclusive process, ${ }^{27}$ involving more than 500 people representing more than 100 organizations (FoKSBI 2017). Going forward, one key goal of the FoKSBI is to coordinate the entire sector to implement the Action Plan.

The multi-stakeholder platform FoKSBI, where representatives from the RSPO and the ISPO can discuss with many different public and private stakeholders how to best cooperate, suggests a novel openness for cross-institutional learning between the two standard schemes. Company representatives and other experts in that context are of the view that the RSPO and the ISPO can co-exist in a cooperative way. At the same time, some private actors, who tend to be close to the government, are still highly reluctant regarding the RSPO, ${ }^{28}$ including the Indonesian company Astra Agro Lestari, which is not always helpful to promote alignment. And while the Indonesian government does facilitate RSPO meetings and participates in them (which is possible because of good personal relations between RSPO advisers and ministry officials), during these meetings government officials often criticize RSPO, for instance for serving the interest of Western countries. ${ }^{29}$

The relationship between the different standard schemes is also shaped by competition across different ministries. While the FoKSBI and the NAP are under the leadership of the Ministry of Agriculture, the ISPO Strengthening process is under the lead of the Coordinating Ministry of Economic Affairs and there does not seem to be any systematic meta-coordination. In the context of leading the NAP, the Ministry of Agriculture was able to stretch its responsibilities beyond its original authority limited to the "farm" because other ministries used to be less interested in governing palm oil and UNDP expertise and resources supported the Ministry in developing the FoKSBI and the NAP process; but since palm oil has become a "strategy commodity" in 2015, and in light of slow progress with respect to the ISPO, the President authorized the Coordinating Ministry of Economic Affairs to take the lead in the "ISPO Strengthening" process (van der Elst 2018). While the NAP and "Strengthening ISPO" could complement each other in many ways, for example regarding smallholder support, inter-ministerial competition in the palm oil sector and overlapping policies and processes at times undermines coordination and the creation of synergies.

Still, despite these complications, there are many productive interactions that display cooperation between the standards. For instance, while the Indonesian state

\footnotetext{
27 Interview, 7 January 2020.

28 Interview, 11 December 2019.

29 Interview, 13 December 2019.
} 
does not aim at making ISPO equivalent to RSPO, the government does continuously make use of platforms like FoKSBI to discuss how to strengthen and improve ISPO (Nesadurai 2019). For example, during a FoKSBI dialogue in November 2019 on Learning from Palm Oil Sustainability Certification Practices, the Director General of Plantations, Kasdi Subagyono stressed in his concluding remarks that ISPO must learn from other schemes such as RSPO and greatly appreciate RSPO providing input to ISPO (FoKSBI 2019).

In sum, the analysis of these mechanisms illustrates that the interaction between RSPO and ISPO, despite their initial competitive nature and the risk of fragmentation, has generated regular productive interactions. The analysis has also shown that the interaction between RSPO and ISPO does not lead to a race to the bottom but rather to the standards converging upwards. The examination of the evolving interaction between different palm oil standards confirms earlier studies that find that the Indonesian government aimed at reclaiming its authority. But while Indonesian state actors are strongly involved in steering the palm oil sector, the above analysis demonstrates that many elements of the governance architecture and the interaction between different governance approaches have become more participatory over time, which has contributed to mutual learning and some convergence.

\section{Towards a Joined-up Transnational Regime for Sustainable Palm Oil?}

Although there is still no overarching global palm oil governance regime, the interaction between different standards examined in this article suggests that an increasingly joined-up transnational regime for sustainable palm oil is evolving. As suggested by Zeitlin and Overdevest (2019), the emergence of such a joined-up regime can be characterized by the following four elements: convergence around shared definitions, the diffusion of reciprocally strengthening rules and standards, the institutionalization of cooperation as well as comparative monitoring, review and revision of different approaches.

First, there is increasing "convergence among actors and initiatives around a shared problem definition and accompanying norms, principles" (Zeitlin and Overdevest 2019, p. 6) in palm oil governance. While there are still some discussions about what exactly constitutes sustainability in the sector, for example, what exactly constitutes deforestation, there is agreement that deforestation is in conflict with sustainability. More generally, there are much fewer fundamental disputes about how to define sustainable palm oil than were ongoing when ISPO was initially established. For instance, this is also exemplified by the fact that the concept of HCV is now incorporated into ISPO.

Second, we can witness the "diffusion of mutually reinforcing and often explicitly cross-referencing rules and standards across jurisdictions and schemes (both public and private)" (Zeitlin and Overdevest 2019, p. 6) in the palm oil sector. As discussed above, principles and rules of RSPO have been spreading to ISPO. Moreover, there is also a diffusion of the idea of supply chain standards for palm oil that seek to go beyond the current practice of certifying crude palm oil. In light of supply chain schemes being developed by RSPO and MSPO, there have been initiatives that seek 
to prepare a supply chain standard for ISPO in collaboration with the Ministry of Industry which covers crude palm oil but also its derivative products throughout the supply chain rather than merely oil palm plantations and associated mills. While the Ministry of Industry has argued that the Indonesian government should adopt value chain certification in line with international trends, the Ministry of Agriculture does not support this plan, arguably also because this would entail a loss of authority for the Ministry (van der Elst 2018). Another example of the diffusion of rules and standards and cross-referencing is the RSPO's revision of their P\&C to create the new standard RSPO-RED that is aligned with the EU Renewable Energy Directive (RED) and allows palm oil producers and processors to comply with requirements in the EU Directive.

Third, there is a growing "institutionalization of practical cooperation among formally autonomous actors and schemes" to promote the goal of sustainable palm oil, including "information sharing, alignment of regulatory approaches and collaborative enforcement activities" (Zeitlin and Overdevest 2019, p. 6). For instance, as laid out above, the FoKSBI has institutionalized regular meetings to share information and to align the ISPO and the RSPO. There are also collaborative enforcement and implementation activities. For example, RSPO is supporting ISPO implementation on the ground by helping to finalize ISPO independent smallholder certification in Jambi. $^{30}$

In addition, cooperation on standard schemes has also been institutionalized across national boundaries. In 2015, the Malaysian and Indonesian governments established the intergovernmental Council of Palm Oil Producing Countries (CPOPC) to better align the ISPO and the MPSO and also to work together on safeguarding palm oil markets (Ministry of Plantation Industries and Commodities 2016), especially in light of the EU's policy reforms that are expected to lead to a phase-out of palm oil as a biofuel in Europe. The Council is regarded as a good platform to cooperate, as underlined by a representative of a palm oil company. ${ }^{31}$ While Indonesia and Malaysia are competitors as large palm oil producers, they joined forces to object to the revised EU RED and plan to challenge the EU policy through the WTO's dispute settlement body. Indonesia's Deputy Minister for Coordinating of Economic Affairs Musdhalifah Machmud said both countries "needed to build on matters in common rather than harp on differences" and "urged stakeholders to be more coordinated in communicating so as to be stronger in tackling smear campaigns against the palm oil industry" (Ching 2019). Moreover, ISPO and the Indian Palm Oil Sustainability (IPOS) Framework are working together, with Indian consumers "increasingly calling for sustainably-sourced products" (Ha 2020). ${ }^{32}$ In 2018, they signed a Memorandum of Understanding as a basis for the mutual

\footnotetext{
30 Interview, 11 December 2019.

31 On the other hand, there are also experts with more sceptical voices that view the Council as a "lip service" by the government. Interview, 11 December 2019.

${ }^{32}$ Sustainability standards have traditionally faced challenging territory in emerging economies like China and India. But recent research indicates that sustainable palm oil is gaining some traction in these countries (Schleifer and Sun 2018).
} 
recognition of ISPO and IPOS for sustainable palm oil production and trade between Indonesia and India (Sapp 2018), the largest market for Indonesian palm oil exports.

Fourth, there is a growing spotlight on "monitoring, review, and revision of practices, procedures, and programs at multiple levels" based on information gathered by comparing the standard schemes and pertinent implementation experiences (Zeitlin and Overdevest 2019, p. 6). In the context of the Indonesian palm oil sector, a key example of such a review is the joint report by ISPO and RSPO, which also takes account of implementation challenges on the ground (Suharto et al. 2015).

All in all, the analysis of the above-mentioned four elements shows that something like a joined-up transnational regime for palm oil has started to emerge. The article thus supports the findings of earlier research (Overdevest and Zeitlin 2014) which show that such a regime "can be assembled piece-by-piece under polyarchic conditions through coordinated learning from decentralized experimentation, without a hegemonic power to impose common global rules" (Zeitlin and Overdevest 2019, p. 35).

\section{Conclusion}

This article has shown that the experimentalist architecture of palm oil governance has fostered coordination across public and private certification schemes as well as with public regulation and has helped to join up the separate components of the regime complex through productive interactions. At the same time, the various different and often contradictory perceptions among actors on palm oil that shape the evolution of the sustainability of the sector complicate coordination and cooperation. Moreover, there are still numerous challenges in the Indonesian palm oil sector that need to be tackled, for instance concerning smallholder certification. While RSPO has developed new P\&C for smallholders, this has not been done in the case of ISPO, thereby risking the exclusion of smallholders from being certified under this standard and despite the government aiming at certifying smallholders under the ISPO until 2025. ${ }^{33}$ Significant gaps and challenges thus remain within the emerging palm oil regime, also because of the multiple different views of the many actors engaged in the palm oil sector.

By providing novel insights into the evolving nature of the interaction between private-driven and public-driven governance initiatives, this article sheds new light on transnational business governance interactions. It contributes to the burgeoning literature on transnational interlinkages by showing how the analysis of transnational governance interactions can be fruitfully investigated through the theoretical lens of experimentalist governance. It shows that governance in the context of the palm oil sector and the sustainability challenges it generates lead to shifts in responsibility between public and private actors and the introduction of innovative governance arrangements. It also shows that the interaction between ISPO and the

\footnotetext{
33 Interview, 11 December 2019. For a discussion of smallholders in the context of RSPO certification, see Brandi et al. (2015).
} 
RSPO was initially characterized by competition but has been increasingly shaped by cooperation and coordination. The changing perspectives of the Indonesia state on the RSPO, ISPO and the relationship between the different standards are driven by the increasing recognition of the difficulties of the ISPO in gaining traction and increasing incentives due to changing EU policies. The evolving relationship is also shaped by the wide variety of diverse public and private actors involved in the palm oil sector and thus shaped by the fragmented nature of the Indonesian state and the interests of different private actors. The findings of this article suggest, in line with previous research (Giessen et al. 2016, p. 85), that the shift in the standards and certification landscape is typically initiated and shaped by domestic state actors and not only by new changing international constellations, which might indicate that the future of transnational and international regimes strongly hinges on domestic publicsector actors and their interests, norms and capacities.

The multitude of existing standards in the palm oil sector and beyond it may prevent many companies from participating in international trade and creates inefficiencies in the standard system, such as market participants incurring multiple costs in order to comply with duplicate standards or with different standards for distinct target markets. The coordination and harmonization of standards can thus lead to substantial gains. Existing studies suggest that approximately one-third of global trade in goods is influenced by standards, and that "the boost in trade from the complete international harmonization of product standards would be equivalent to the reduction of tariffs by several percentage points" (Büthe and Walter 2011, p. 8). Future research could investigate in more detail how the interaction between private-driven and public-driven governance initiatives affect regulatory effectiveness and the environmental, social, and economic sustainability of the sectors under consideration in the long run. Future research should also explore in more detail how emerging economies such as China and India, and their increasing demand for sustainable palm oil, are shaping these different governance approaches, their interlinkages and their effectiveness.

\section{Compliance with Ethical Standards}

Conflict of interest The author declares that he has no conflict of interest.

Funding Open Access funding provided by Projekt DEAL.

Open Access This article is licensed under a Creative Commons Attribution 4.0 International License, which permits use, sharing, adaptation, distribution and reproduction in any medium or format, as long as you give appropriate credit to the original author(s) and the source, provide a link to the Creative Commons licence, and indicate if changes were made. The images or other third party material in this article are included in the article's Creative Commons licence, unless indicated otherwise in a credit line to the material. If material is not included in the article's Creative Commons licence and your intended use is not permitted by statutory regulation or exceeds the permitted use, you will need to obtain permission directly from the copyright holder. To view a copy of this licence, visit http://creativecommons.org/licen ses/by/4.0/. 


\section{References}

Abbott, K.W. 2012. The transnational regime complex for climate change. Environment and Planning C: Government and Policy 30 (4): 571-590.

Abbott, K.W. 2014. Strengthening the transnational regime complex for climate change. Transnational Environmental Law 3 (1): 57-88.

Abbott, K.W., and D. Snidal. 2009. Strengthening international regulation through transnational new governance: Overcoming the orchestration deficit. Vanderbilt Journal of Transnational Law 42: 501-578.

Adnan, H. 2013. National Palm Oil Standard soon. The Star, 21 March. https://www.thestar.com.my/ business/business-news/2013/03/21/national-palm-oil-standard-soon. Accessed 7 January 2020.

Aisyah, R. 2018. Stronger rule to back ISPO delayed. The Jakarta Post, 3 December. http://www.thejakartapost.com/news/2018/12/03/stronger-rule-back-ispo-delayed.html. Accessed 7 January 2020.

Akhlas, A.W. 2019. Indonesia looks to strengthen palm oil industry through ISPO, domestic market, The Jakarta Post, 6 November. https://www.thejakartapost.com/news/2019/11/06/indonesia-looks-tostrengthen-palm-oil-industry-through-ispo-domestic-market.html. Accessed 7 January 2020.

Alter, K.J., and S. Meunier. 2009. The politics of international regime complexity. Perspectives on Politics 7: 13-24.

Astari, A.J., and J.C. Lovett. 2019. Does the rise of transnational governance 'hollow-out' the state? Discourse analysis of the mandatory Indonesian sustainable palm oil policy. World Development 117: $1-12$.

Bartley, T. 2007. Institutional emergence in an era of globalization: The rise of transnational private regulation of labor and environmental conditions. American Journal of Sociology 113: 297-351.

Bartley, T. 2014. Transnational governance and the re-centered state: Sustainability or legality? Regulation and Governance 8: 93-109.

Bell, S., and A. Hindmoor. 2012. Governance without government? The case of the forest stewardship council. Public Administration 90 (1): 144-159.

Bernstein, S., and B. Cashore. 2007. Can non-state global governance be legitimate? An analytical framework. Regulation \& Governance 1 (4): 347-371.

Biermann, F., P. Pattberg, H. Van Asselt, and F. Zelli. 2009. The fragmentation of global governance architectures: A framework for analysis. Global Environmental Politics 9 (4): 14-40.

Brandi, C., T. Cabani, C. Hosang, S. Schirmbeck, L. Westermann, and H. Wiese. 2015. Sustainability standards for palm oil: Challenges for smallholder certification under the RSPO. The Journal of Environment \& Development 24 (3): 292-314.

Büthe, T. 2010. Engineering uncontestedness? The origins and institutional development of the International Electrotechnical Commission (IEC). Business and Politics 12 (3): 1-62.

Büthe, T., and M. Walter (eds.). 2011. The new global rulers: The privatization of regulation in the world economy. Princeton, NJ: Princeton University Press.

Cashore, B. 2002. Legitimacy and the privatization of environmental governance: How Non-State Market Driven (NSDM) governance systems gain rule making authority. Governance 15: 503-529.

Cashore, B., G. Auld, and D. Newsom (eds.). 2004. Governing through markets: Forest certification and the emergence of non-state authority. New Haven, CT: Yale University Press.

Ching, O. T. 2019. CPOPC to rise up in fighting smear campaign against palm oil. 23 October. https ://www.nst.com.my/news/exclusive/2019/10/532544/cpopc-rise-fighting-smear-campaign-againstpalm-oil. Accessed 8 January 2020.

Damodaranuala, R. 2014. RSPO keen to collaborate on certification. New Straits Time Online, 19 November. http://www.nst.com.my/node/54513. Accessed 28 October 2015.

Dingwerth, K. 2008. Private transnational governance and the developing world: A comparative perspective. International Studies Quarterly 52 (3): 607-634.

Eberlein, B., K.W. Abbott, J. Black, E. Meidinger, and S. Wood. 2014. Transnational business governance interactions: Conceptualization and framework for analysis. Regulation and Governance 8 (1): $1-21$.

FoKSBI. 2019. Dialogue of the palm oil stakeholders lessons learned from palm oil sustainability certification practices. 12 November. http://foksbi.id/en/news/read/11-12-2019-dialogue-of-the-palmoil-stakeholders-lessons-learned-from-palm-oil-sustainability-certification-practices. Accessed 7 January 2020. 
Forest Peoples Programme. 2017. A comparison of leading palm oil certification standards. https://www. forestpeoples.org/en/responsible-finance-palm-oil-rspo/report/2017/comparison-leading-palm-oilcertification-standards. Accessed 7 January 2020.

Forest Watch Indonesia. 2017. Indonesian civil society groups' position paper on sustainable palm oil industry in Indonesia. http://fwi.or.id/english/publikasi/indonesian-civil-society-groups-positionpaper-on-sustainable-palm-oil-industry-in-indonesia/. Accessed 7 January 2020.

Fransen, L. 2011. Why do private governance organizations not converge? A political-institutional analysis of transnational labor standards regulation. Governance 24 (2): 359-387.

Giessen, L., S. Burns, A. Sahide, and A. Wibowo. 2016. Governance to government: The strengthened role of state bureaucracies in forest and agricultural certification. Policy and Society 35 (1): 71-89.

Grazella, M. 2014. Thousands of palm oil firms to miss certification. The Jakarta Post, 3 March. http:// www.thejakartapost.com/news/2014/03/03/thousands-palm-oil-firms-miss-certification.html. Accessed 7 January 2020.

Gulbrandsen, L.H. 2014. Dynamic governance interactions: Evolutionary effects of state responses to non-state certification programs. Regulation \& Governance 8: 74-92.

Ha, T. 2020. Will India's curb on Malaysian palm oil hurt Indonesian forests? Eco-Business, 5 February. https://www.eco-business.com/news/will-indias-curb-on-malaysian-palm-oil-hurt-indonesian-fores ts/. Accessed 24 July 2020.

Hakim, M. 2010. Go to hell RSPO and welcome ISPO. Mediaperkebunan. http://mediaperkebunan.net/ index.php?option=com_contentandview $=$ articleandid=51:go-to-hell-rspo-and-welcome-ispoandcat $\mathrm{id}=9$ :publikasiandItemid=5. Accessed 7 January 2020.

Haryana, A., Indarto, J., and Avianto, N. (2010) Kebijakan dan Strategi Dalam Meningkatkan Nilai Tambahdan Daya Saing Kelapa Sawit Indonesia Secara Berkelanjutandan Berkeadilan. Naskah Kebijakan (Policy Paper). Jakarta, Direktorat Pangandan Pertanian BAPPENAS. https://www.bappenas. go.id/files/1813/5182/6723/naskah-kebijakan-final-sawit_20110211150840_4.pdf. Accessed 7 January 2020.

Hickmann, T., H. van Asselt, S. Oberthür, L. Sanderink, O. Widerberg, and F. Zelli. 2020. Institutional interlinkages. In Architectures of earth system governance: Institutional complexity and structural transformation, ed. F. Biermann and R.E. Kim, 119-136. Cambridge: Cambridge University Press.

Hidayat, N.K., A. Offermans, and P. Glasbergen. 2018. Sustainable palm oil as a public responsibility? On the governance capacity of Indonesian Standard for Sustainable Palm Oil (ISPO). Agriculture and Human Values 35: 223-242.

Hospes, O. 2014. Marking the success or end of global multi-stakeholder governance? The rise of national sustainability standards in Indonesia and Brazil for palm oil and soy. Agriculture and Human Values 31 (3): 425-437.

Hospes, O., and A. Kentin. 2012. Tensions between global scale and national scale governance: The strategic use of scale frames to promote sustainable palm oil production in Indonesia. In Scale-sensitive governance of the environment, ed. F. Padt, P. Opdam, N. Polman, and C. Termeer, 203-219. WileyBlackwell: Hoboken, NJ.

Hysing, E. 2009. Governing with government? The private governance of forest certification in Sweden. Public Administration 87 (2): 312-326.

IUCN. 2019. Setting the biodiversity bar for palm oil certification. https://www.iucn.nl/en/updates/iucnnl-compares-sustainability-certification-for-palm-oil. Accessed 7 January 2020.

Jakarta Post. 2010. Indonesia develops rival sustainable palm oil scheme. 10 November. http://www. thejakartapost.com/news/2010/11/10/indonesia-develops-rival-sustainable-palm-oil-scheme.html. Accessed 7 January 2020.

Jakarta Post. 2011. GAPKI withdraws from RSPO to support ISPO. 5 October. http://www.thejakarta post.com/news/2011/10/05/gapki-withdraws-rspo-support-ispo.html. Accessed 7 January 2020.

Kentin, A. 2012. Scale Frames, the RSPO and GAPKI: The development of principles and partnerships to promote sustainable palm oil in Indonesia. Master thesis. Wageningen University, Wageningen, The Netherlands.

Lederer, M., L. Wallbott, and S. Bauer. 2018. Tracing sustainability transformations and drivers of Green Economy approaches in the Global South. Journal of Environment \& Development 27 (1): 3-25.

Lubis, A.M. 2013. More companies obtain sustainable certification. The Jakarta Post, 21 August. http:// www.thejakartapost.com/news/2013/08/21/more-companies-obtain-sustainable-certification.html. Accessed 7 January 2020.

Meidinger, E. 2008. Competitive supragovernmental regulation: How could it be democratic? Chicago Journal of International Law 8: 513-534. 
Ministry of Plantation Industries and Commodities. 2016. Ministerial Meeting: The Council of Palm Oil Producing Countries, MPIC. https://www.mpic.gov.my/mpic/index.php/en/media-feedback/65maklumbalas-kepada-media-2016-bi/657-establishment-of-the-council-of-palm-oil-producingcountries-cpopc. Accessed 7 January 2020.

Nesadurai, H.E. 2019. Transnational private governance as a developmental driver in Southeast Asia: The case of sustainable palm oil standards in Indonesia and Malaysia. The Journal of Development Studies 55 (9): 1892-1908.

Oberthür, S., and O.S. Stokke (eds.). 2011. Managing institutional complexity: Regime interplay and global environmental change. Cambridge, MA: MIT Press.

Obidzinski, K., A. Dermawan, A. Andrianto, H. Komarudin, and D. Hernawan. 2014. The timber legality verification system and the voluntary partnership agreement (VPA) in Indonesia: Challenges for the small-scale forestry sector. Forest Policy and Economics 48: 24-32.

Overdevest, C. 2010. Comparing forest certification schemes: The case of ratcheting standards in the forest sector. Socio-Economic Review 8 (1): 47-76.

Overdevest, C., and J. Zeitlin. 2014. Assembling an experimentalist regime: Transnational governance interactions in the forest sector. Regulation \& Governance 8 (1): 22-48.

Overdevest, C., and J. Zeitlin. 2018. Experimentalism in transnational forest governance: Implementing European Union Forest Law Enforcement, Governance and Trade (FLEGT) Voluntary Partnership Agreements in Indonesia and Ghana. Regulation \& Governance 12 (1): 64-87.

Pacheco, P., G. Schoneveld, A. Dermawan, H. Komarudin, and M. Djama. 2018. Governing sustainable palm oil supply: Disconnects, complementarities, and antagonisms between state regulations and private standards. Regulation and Governance. https://doi.org/10.1111/rego.12220.

Pattberg, P.H. 2012. Transnational environmental regimes. In Global environmental governance reconsidered, ed. F. Biermann and P.H. Pattberg. Cambridge, MA: MIT Press.

Pradipta, T. 2018. ISPO Dilemma in Indonesia palm oil industry, The Palm Oil Scribe, 18 May. https ://thepalmscribe.id/rosediana-suharto-ispo-dilemma-in-indonesia-palm-oil-industry. Accessed 7 January 2020.

Pramudya, E.P., O. Hospes, and C.J.A.M. Termeer. 2018. Friend or foe? The various responses of the Indonesian state to sustainable non-state palm oil initiatives. Asian Journal of Sustainability and Social Responsibility 3 (1): 1.

Raustiala, K., and D.G. Victor. 2004. The regime complex for plant genetic resources. International Organization 58 (2): 277-309.

RSPO. 2014. Indonesian Vice-Minister of Trade and RSPO open to collaboration on Sustainable Palm Oil Stand. 6 June. http://www.rspo.org/news-and-events/news/indonesian-trade-viceministerand-rspo-open-to-collaboration-on-joint-sustainable-palm-oil-stand. Accessed 7 January 2020.

Sapp, M. 2018. Solidaridad brings together Asian palm oil industries into sustainability framework. Biofuels Digest, 17 July. https://www.biofuelsdigest.com/bdigest/2018/07/17/solidaridad-bring s-together-asian-palm-oil-industries-into-sustainability-framework/. Accessed 24 July 2020.

Schleifer, P., and Y. Sun. 2018. Emerging markets and private governance: The political economy of sustainable palm oil in China and India. Review of International Political Economy 25 (2): 190-214.

Smith, T.M., and M. Fischlein. 2010. Rival private governance networks: Competing to define the rules of sustainability performance. Global Environmental Change 20: 511-522.

Subagyo. 2013. Kementan Berharap ISPO Jadi Syarat RSPO. Antara, 10 May. https://www.antar anews.com/berita/374033/kementan-berharap-ispo-jadi-syarat-rspo. Accessed 7 January 2020.

Suharto, R. 2010. Why Indonesia needs ISPO. The Jakarta Post, 2 December. http://www.thejakarta post.com/news/2010/12/02/why-indonesia-needs-ispo.html. Accessed 7 January 2020.

Suharto, R., K. Husein, K.D. Sartono, A. Darussamin, P. Hariyadi, et al. 2015. Joint Study on the similarities and differences on the ISPO and the RSPO certification systems. Bogor, Indonesia: ISPO, RSPO, UNDP.

Suwarganda, I. 2020. Indonesian Sustainable Palm Oil (ISPO) Fact Sheet. https://goldenagri.com.sg/ wp-content/uploads/2020/06/Indonesian-Sustainable-Palm-Oil-ISPO-Fact-Sheet.pdf. Accessed 24 July 2020.

TROPIS. 2011. And the reason is clear (interview with Fadhil Hasan). TROPIS Economy and Environment, Special Edition. November.

van der Elst, G.W. 2018. Creating legitimacy for the Indonesian Sustainable palm oil certification scheme. Master Thesis. Wageningen University, Wageningen, The Netherlands. 
Wadley, J. and Doherty, F. 2013. Illegal fires put "sustainable" palm oil in the hot spot. Environmental Investigation Agency, 21 June. https://eia-international.org/news/sustainable-palm-oil-in-the-hotspot/. Accessed 7 January 2020.

Wijaya, A., and P. Glasbergen. 2016. Toward a new scenario in agricultural sustainability certification? The response of the Indonesian national government to private certification. The Journal of Environment and Development 25 (2): 219-246.

Zeitlin, J. and Overdevest, C. 2019. Experimentalist interactions: FLEGT and the transnational timber legality regime. Amsterdam Centre for European Studies Research Paper 4.

Zelli, F., and H. van Asselt. 2013. The institutional fragmentation of global environmental governance: Causes, consequences, and responses. Global Environmental Politics 13 (3): 1-13.

Publisher's Note Springer Nature remains neutral with regard to jurisdictional claims in published maps and institutional affiliations. 